\title{
Soil characterization and heavy metal pollution assessment in Orabi farms, El Obour, Egypt
}

\author{
Salman A. Salman', Salah A. M. Zeid², El-Montser M. Seleem² and Mahmoud A. Abdel-Hafiz ${ }^{2 *}$ (D)
}

\begin{abstract}
Background: Soil pollution negatively impacts on food safety and human health. The main aim of this work is to determine the As, $\mathrm{Cd}, \mathrm{Cr}, \mathrm{Cu}$, and Pb concentrations in Orabi farms, El Obour city, Egypt. The contamination of soil with these metals was assessed by contamination factors (CF), degree of contamination (DC), pollution load index (PLI), ecological risk factor (Er), potential ecological risk index (PRI), and index of geoaccumulation (Igeo). Eleven soil samples were collected from Orabi farms and analyzed for physicochemical characteristics.

Results: The results indicate that Orabi soils are considered alkaline $(\mathrm{pH}=8.11)$, weakly calcareous $\left(\mathrm{CaCO}_{3}=3.6 \%\right)$, sandy (sand $=90.23 \%)$ soils, and non-saline to slightly saline $(E C=4840.68 \mu \mathrm{S} / \mathrm{cm})$ in nature. In addition, it contains negligible organic matter percent $(\mathrm{OM}=3.15 \%)$ and so it is classified as mineral soil. The average concentrations of As, $\mathrm{Cd}, \mathrm{Cr}, \mathrm{Cu}$, and $\mathrm{Pb}$ were 147.46, 2.31, 44.50, 4.10, and $13.01 \mathrm{mg} / \mathrm{kg}$, respectively.

Conclusion: The calculated $I_{\text {geo, }} \mathrm{CF}$, and Er recorded that investigated soil samples are uncontaminated with $\mathrm{Cr}, \mathrm{Cu}$, and $\mathrm{Pb}$, considerably contaminated with $\mathrm{Cd}$, and highly contaminated with As. The calculated integrated pollution indices PRI, PLI, and DC showed that soil samples were contaminated with the studied heavy metals. The high CF values of $\mathrm{As}$ and $\mathrm{Cd}$ are the main contributor to soil high contamination. The application of fertilizers and other agricultural practice in the study area must be paid attention.
\end{abstract}

Keywords: Organic matter, Heavy metals, Contamination factor, Pollution load index, Orabi farms

\section{Background}

Soil pollution is often thought as a result of chemical contamination. The use of poor quality water and the application of excessive amounts of pesticides and fertilizers can result in soil contamination. As well as waterlogging can lead to soil degradation and yield reduction (Singh 2015; Abdel-Hafiz 2017; Zeid et al. 2018). The soil is classified as contaminated when metal concentrations in its bulk horizons exceed baseline values taken as higher limits for noncontaminated soils (Kabata-pendias and Pendias 2001; Proust et al. 2013). Polluted water and soil pose a serious threat to plants, affecting crops and thus causing health risks by entering the food chain. Soil pollution has negative effects on food safety as well as result in increased health risks

\footnotetext{
*Correspondence: drmahmoud1713@gmail.com;

Elkarim_mahmoud@azhar.edu.eg

${ }^{2}$ Geology Department, Faculty of Science, Al-Azhar University, Assiut, Egypt Full list of author information is available at the end of the article
}

(Suresh and Nagesh 2015; Yonglong et al. 2015; Salman et al. 2016a).

The texture as well as physicochemical properties of soils affect its heavy metal contents and control directly or indirectly the nature of reactions that occur on the surfaces of their constituting particles (Manahan 1994; He et al. 2005).

Pollution indices are a powerful tool for environmental quality assessment. The commonly used pollution indices for heavy metals in soils are classified into two types, single and integrated pollution index (Yuan et al. 2004, Qingjie et al. 2008; Hafizur Rahman et al. 2012). In the present study, three single indices, namely index of geoaccumulation $\left(I_{\text {geo }}\right)$, contamination factor $(\mathrm{CF})$ and ecological risk factor (Er), as well as three integrated indices; degree of contamination (DC), pollution load index (PLI), and potential ecological risk index (PRI) were used. Integrated pollution indices for the studied samples were determined to build a broad overview of 
the extent of contamination of the area by the various heavy metals. It is well known that most of metal and metalloid contamination in the surface environment is associated with all contaminant metals rather than one metal (Chon et al. 1997; Swapnil et al. 2011; Elnazer et al. 2015).

The scope of the present study is to determine the general characteristics of soil $\left(\mathrm{pH}, \mathrm{EC}, \mathrm{PSD}, \mathrm{CaCO}_{3}\right.$, and $\mathrm{OM}$ ) and content of $\mathrm{As}, \mathrm{Cd}, \mathrm{Cr}, \mathrm{Cu}$, and $\mathrm{Pb}$ metals. As well as the calculation of different single $\left(I_{\text {geo }}, \mathrm{CF}\right.$, and $\mathrm{Er}$ ) and integrated (DC, PLI, and PRI) pollution indices to assess soil quality.

\section{Methods}

\section{Sampling and methods for physicochemical analysis}

Orabi area represents the eastern part of El Obour city that is considered as one of the most important fruits and vegetable farms in Cairo and located on the eastern side of the Nile Delta. The area is bordered by the Cairo-Belbeis road in the west and northwest and the Cairo-Ismailia highway in the south.

Eleven surface soil samples were collected at depths $0-30 \mathrm{~cm}$ from different sites in Orabi farms (Fig. 1). The selected samples were collected from the vegetable fields (Fig. 2). Soil samples were transferred to the laboratory of geological sciences department, National Research Centre for analyses. After being air-dried, they were sieved through a $2 \mathrm{~mm}$ sieve. Soil $\mathrm{pH}$ was measured in 1:1 soil to water ratio. Soil salinity was determined by measuring the electrical conductivity of a solution extracted from a water-saturated soil paste (1:1) (Tam and Wong 1998; Zhang et al. 2003). Calcium carbonate $\left(\mathrm{CaCO}_{3}\right)$ was estimated by titrimetric method according to USDA (1996). The organic content was determined by Walkley-Black wet combustion method (Walkley 1947; USDA 1996). The hydrometer (ASTM 152H) method was applied for particle-size analysis (Bashour and Sayegh 2007).

For determination of heavy metal concentration, exactly $1 \mathrm{~g}$ of pulverized sample was digested with aqua regia $\left(1 \mathrm{HNO}_{3}: 3 \mathrm{HCl}\right)$ and analyzed for $\mathrm{As}, \mathrm{Cd}, \mathrm{Cr}, \mathrm{Cu}$, and $\mathrm{Pb}$ using atomic absorption spectrometer (Perkin elmer 400).

\section{Pollution risk assessment Single pollution indices}

The $I_{\text {geo }}$ was computed using the following equation (Muller 1979):

$$
I_{\text {geo }}=\log _{2}\left(C_{n} / 1.5 \times B_{n}\right)
$$

where $C_{\mathrm{n}}$ is the measured concentration of heavy metals in soil and $B_{\mathrm{n}}$ is the reference values expressed here as worldwide soils average; $\mathrm{As}=5, \mathrm{Cd}=0.5, \mathrm{Cr}=54$, $\mathrm{Cu}=25$, and $\mathrm{Pb}=25 \mathrm{mg} / \mathrm{kg}$ (Kabata-pendias and Mukherjee 2007).

The constant 1.5 is used for the possible variations of the background data due to the lithogenic effects.

The CF is computed using the following equation (Hakanson 1980):

$$
\mathrm{CF}=C_{\mathrm{s}} / C_{0}
$$

Where $C_{\mathrm{s}}$ is the concentration of metal in the studied sample and $C_{0}$ is baseline concentration (mean worldwide soils).

The Er of a given contaminant was suggested by Hakanson (1980) as follows:

$$
E r=\operatorname{Tr} \times C F
$$

where $\mathrm{CF}$ is contamination factor and the $\mathrm{Tr}$ is "toxic-response" factor for a given metals; $\mathrm{As}=10, \mathrm{Cd}=30$, $\mathrm{Cr}=2, \mathrm{Cu}=5$, and $\mathrm{Pb}=5$ (Hakanson 1980).

\section{Integrated pollution indices}

The DC defined as the sum of all contamination factors (Hakanson 1980):

$$
D C=\sum_{1}^{n} C F
$$

where $\mathrm{CF}$ is the single contamination factor and is the count of the elements present.

The PLI of a single site is the root of number $(n)$ of multiplied together CF values. The formulas applied are as follows (Tomilson et al. 1980):

$$
P L I=\left(C F_{1} \times C F_{2} \times C F_{3} \times \ldots \ldots \ldots \times C F_{n}\right)^{1 / n}
$$

where $n$ is the number of metals studied.

The PRI is defined as the sum of Er (Hakanson 1980):

$$
P R I=\sum_{1}^{n} E r
$$

Each index was ranked into several classes as showed in (Table 1).

\section{Results}

The results of physicochemical characterization of soils ( $\mathrm{pH}$ value, conductivity (EC), calcium carbonate content $\left(\mathrm{CaCO}_{3}\right)$, organic matter $\left.(\mathrm{OM})\right)$ and particle size distributions (PSDs) are illustrated in (Table 2). The values of international standard limits and summary of descriptive statistics for the elements $\mathrm{As}, \mathrm{Cd}, \mathrm{Cr}, \mathrm{Cu}$, and $\mathrm{Pb}$ concentrations in the studied soils are given in (Table 3). Cadmium, chromium, and copper in more than $82 \%$ of the samples as well as all lead contents in the studied soil are below the upper critical limit. The calculated 


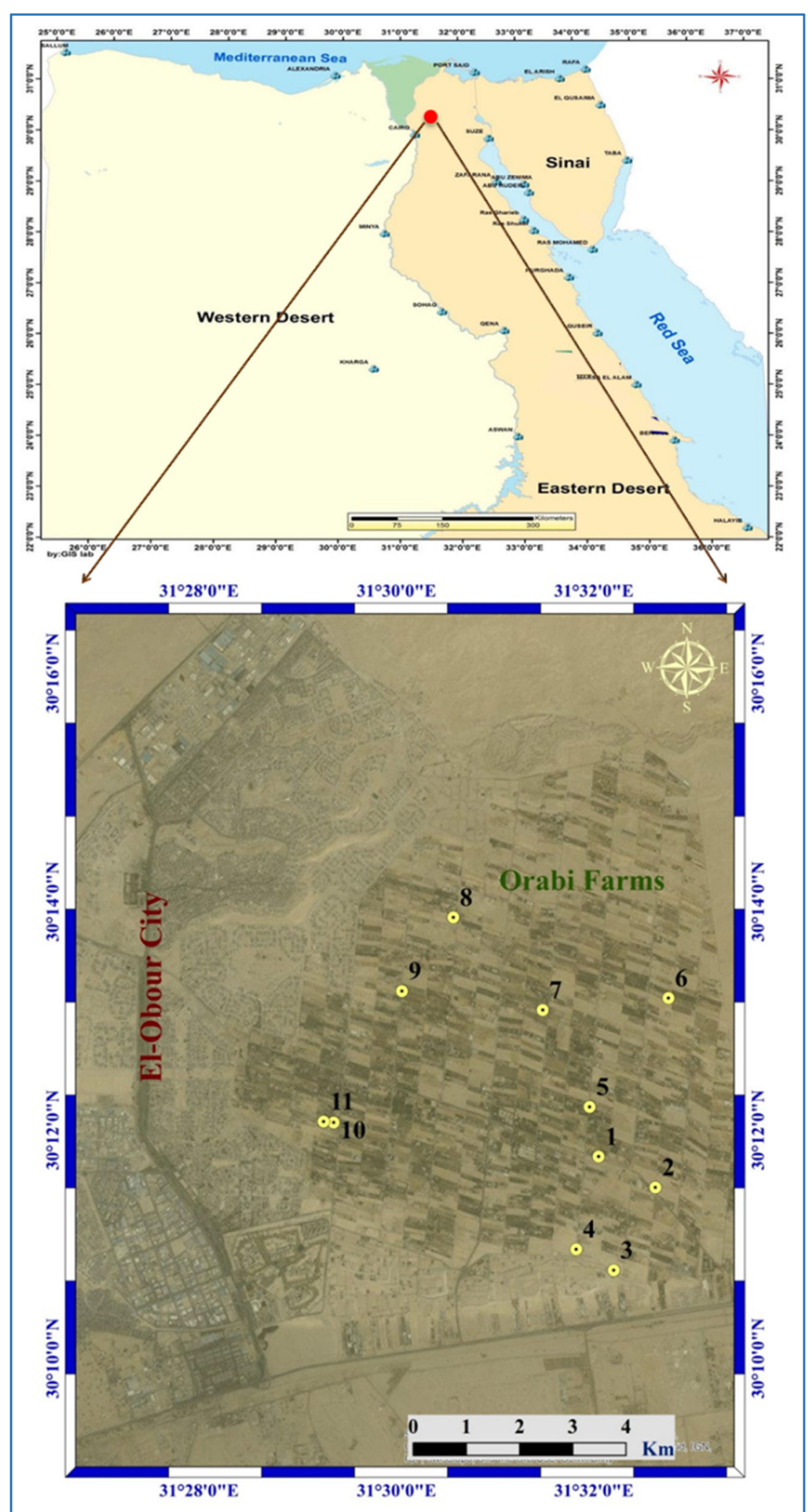

Fig. 1 Location map of the collected soil samples in the study area 


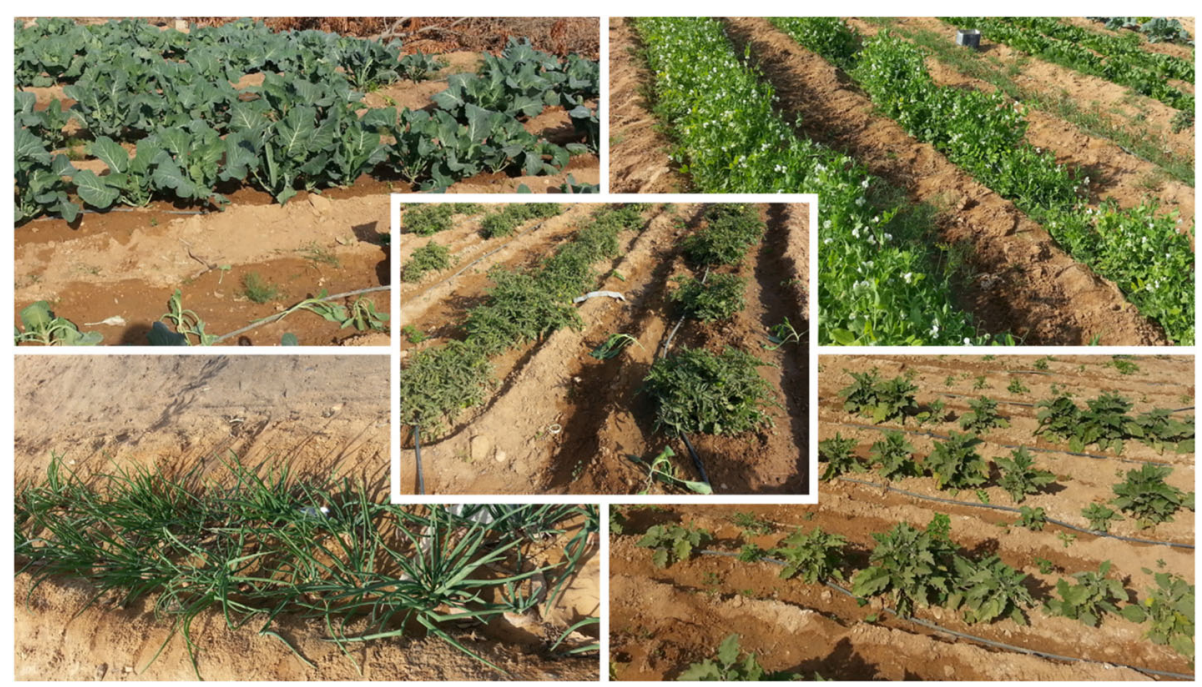

Fig. 2 Photographs showing some cultivated vegetables and sandy nature of soil in Orabi farms

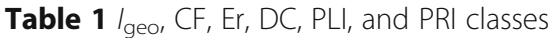

\begin{tabular}{|c|c|c|c|c|}
\hline Index type & & Value & Environmental risk grade & Reference \\
\hline \multirow[t]{16}{*}{ Single indices } & \multirow[t]{7}{*}{ Igeo } & $I_{\text {geo }} \leq 0$ & Practically uncontaminated & \multirow[t]{7}{*}{ (Muller 1979) } \\
\hline & & $0<I_{\text {geo }} \leq 1$ & Uncontaminated to moderately contaminated & \\
\hline & & $1<I_{\text {geo }} \leq 2$ & Moderately contaminated & \\
\hline & & $2<I_{\text {geo }} \leq 3$ & Moderately to heavily contaminated & \\
\hline & & $3<I_{\text {geo }} \leq 4$ & Heavily contaminated & \\
\hline & & $4<I_{\text {geo }} \leq 5$ & Heavily to extremely contaminated & \\
\hline & & $I_{\text {geo }}>5$ & Extremely contaminated & \\
\hline & \multirow[t]{4}{*}{ CF } & $C F<1$ & Low contamination & \multirow[t]{4}{*}{ (Hakanson 1980) } \\
\hline & & $1 \leq C F<3$ & Moderate contamination & \\
\hline & & $3 \leq C F<6$ & Considerable contamination & \\
\hline & & $C F \geq 6$ & High contamination & \\
\hline & \multirow[t]{5}{*}{ Er } & $\mathrm{Er}<40$ & Low potential ecological risk & \multirow[t]{5}{*}{ (Hakanson 1980) } \\
\hline & & $40 \leq \mathrm{Er}<80$ & Moderate potential ecological risk & \\
\hline & & $80 \leq \mathrm{Er}<160$ & Considerable potential ecological risk & \\
\hline & & $160 \leq \mathrm{Er}<320$ & High potential ecological risk & \\
\hline & & $\mathrm{Er} \geq 320$ & Very high ecological risk & \\
\hline \multirow[t]{11}{*}{ Integrated indices } & \multirow[t]{4}{*}{ DC } & $\mathrm{DC}<5$ & Low contamination & \multirow[t]{4}{*}{ (El-Bady and Samy 2014) } \\
\hline & & $5 \leq \mathrm{DC}<10$ & Moderate contamination & \\
\hline & & $10 \leq \mathrm{DC}<20$ & Considerable contamination & \\
\hline & & $D C \geq 20$ & High contamination & \\
\hline & \multirow[t]{3}{*}{ PLI } & $\mathrm{PLI}<1$ & Not polluted & \multirow[t]{3}{*}{ (Tomilson et al. 1980) } \\
\hline & & $\mathrm{PLI}=1$ & Baseline levels of pollutants & \\
\hline & & $\mathrm{PLI}>1$ & Polluted & \\
\hline & \multirow[t]{4}{*}{ PRI } & $\mathrm{PRI}<150$ & Low contamination & \multirow[t]{4}{*}{ (Hakanson 1980) } \\
\hline & & $150 \leq \mathrm{PRI}<300$ & Moderate contamination & \\
\hline & & $300 \leq \mathrm{PRI}<600$ & Considerable contamination & \\
\hline & & $P R I \geq 600$ & High contamination & \\
\hline
\end{tabular}


Table 2 Summary statistics of physicochemical parameters of soil samples in Orabi area

\begin{tabular}{|c|c|c|c|c|c|c|c|}
\hline \multirow[t]{2}{*}{ Parameter } & \multirow[t]{2}{*}{$\mathrm{pH}_{1: 1}$} & \multirow{2}{*}{$\begin{array}{l}\mathrm{EC}_{25} \\
\mu \mathrm{S} / \mathrm{cm}\end{array}$} & \multirow[t]{2}{*}{$\mathrm{CaCO}_{3} \%$} & \multirow[t]{2}{*}{ OM\% } & \multicolumn{3}{|c|}{ Grain size analysis } \\
\hline & & & & & Sand\% & Silt $\%$ & Clay $\%$ \\
\hline Mean & 8.11 & 4840.68 & 3.6 & 0.76 & 90.23 & 1.35 & 8.42 \\
\hline Median & 8.15 & 2098.80 & 3.15 & 0.50 & 91.40 & 0.50 & 8.10 \\
\hline Mode & 8.18 & ND & 2.25 & 0.00 & 91.50 & 0.50 & 8.00 \\
\hline SD & 0.28 & $10,382.76$ & 2.25 & 0.77 & 5.00 & 1.31 & 4.06 \\
\hline Range & 1.11 & $35,550.64$ & 7.65 & 1.95 & 14.70 & 3.70 & 13.50 \\
\hline Min & 7.58 & 464.4 & 0.45 & $\mathrm{BDL}$ & 83.50 & 0.50 & 1.30 \\
\hline Max & 8.69 & 36,015 & 8.10 & 1.95 & 98.20 & 4.20 & 14.80 \\
\hline$Q_{1}$ & 8.02 & 902.57 & 2.25 & 0.09 & 85.85 & 0.50 & 6.75 \\
\hline$Q_{3}$ & 8.20 & 2744.20 & 4.50 & 1.51 & 92.75 & 1.50 & 11.45 \\
\hline
\end{tabular}

SD standard deviation, Min minimum, Max maximum, Q1 1st quartile, Q3 3rd quartile, BDL below detection limit, ND not detected, OM organic matter

single and integrated pollution indices are shown in (Table 4).

\section{Discussion}

\section{Physiochemical characteristics of soil}

The measured $\mathrm{pH}$ values for the studied soils vary from 7.58 to 8.69 (Table 2), indicating the alkaline nature of the soil, which may be attributed to carbonate hydrolysis or lack of rainfall environment (Foth 1990). Geologically, the study area is rich in carbonate rock deposits of Marine Miocene deposits (RIGW 1980; Abdel-Hafiz 2017). The studied soil extracts exhibit a wide variation of electric conductivity (salinity), ranging from 464.4 to $36,015 \mu \mathrm{S} / \mathrm{cm}$.

Richards (1954) has described the general relationship between EC and plant growth (Table 5). Accordingly, the majority investigated soil samples in the study area ranged from non-saline to slightly saline soil. There is one abnormal sample (11) that shows extremely saline soil. The farm owner complained about the lack of soil fertility compared to the adjacent soil (Fig. 3).

Table 3 Summary statistics of heavy metals $(\mathrm{mg} / \mathrm{kg})$ compared with the average of worldwide soil

\begin{tabular}{llllll}
\hline Parameter & $\mathrm{As}$ & $\mathrm{Cd}$ & $\mathrm{Cr}$ & $\mathrm{Cu}$ & $\mathrm{Pb}$ \\
\hline Mean & 147.46 & 2.31 & 44.50 & 4.10 & 13.01 \\
Median & 147.8 & 1.9 & 44.5 & 4.55 & 10.8 \\
SD & 21.60 & 1.48 & 11.89 & 1.55 & 4.57 \\
Min. & 117.5 & 1.5 & 29.05 & 2 & 8.65 \\
Max. & 182.8 & 6.75 & 67.25 & 6.45 & 22.5 \\
Q $_{1}$ & 134.5 & 1.8 & 36.35 & 2.825 & 9.55 \\
Q $_{3}$ & 156.2 & 2 & 49.375 & 5.05 & 14.95 \\
WSA & 5 & 0.5 & 54 & 25 & 25 \\
\hline
\end{tabular}

WSA world soil average (after Kabata-Pendias and Mukherjee 2007)
According to the UNCCD (2005), the process of soil salinization is due to:

- Excessive utilization of irrigation water.

- Inadequate salt leaching practices.

- Inefficient or impaired drainage conditions.

- Evaporation from the water table, especially when it is within $2 \mathrm{~m}$ (waterlogging), significantly contribute to root-zone salinity.

The distribution and amount of carbonates influence soil fertility. The $\mathrm{CaCO}_{3}$ in the studied soil samples varies from 0.45 to $8.1 \%$ with an average of $3.6 \%$ (Table 2). This indicates that all samples can be considered as weakly calcareous soil except samples (1 and 2) considered as moderately calcareous soil (NSSCC 1965).

Organic matter flocculated between BDL and $1.95 \%$ with an average content of $0.76 \%$ (Table 2). This low content of $\mathrm{OM}$ is referred to the desert nature of the study area and the lake of organic additives into soil.

The result of grain size analysis of soil samples shows that sand is averaging $90.23 \%$, silt averaging $1.35 \%$, and clay averaging $8.42 \%$ (Table 2). According to Folk (1974) triangle chart (Fig. 4a), the studied soil samples can be texturally classified as two groups, namely, sand (seven samples) and clayey sand (four samples). On the other hand, it divides into three main groups based on USDA system Soil Survey Staff (1993); sandy loam (one sample), loamy sand (three samples), and sand (seven samples) (Fig. 4b).

\section{Heavy metals}

The soil may be contaminated by the accumulation of toxic metals through emissions from the industrial activities, land application of fertilizers, pesticides, spillage of 
Table 4 Summary statistics of $I_{\text {geo, }}$ CF, Er, DC, PLI, and PRI for the determined elements

\begin{tabular}{|c|c|c|c|c|c|c|c|c|c|c|c|c|c|c|c|c|c|c|}
\hline \multirow[t]{3}{*}{ Parameter } & \multicolumn{15}{|c|}{ Single indices } & \multirow{2}{*}{\multicolumn{3}{|c|}{ Integrated indices }} \\
\hline & \multicolumn{5}{|l|}{ Igeo } & \multicolumn{5}{|l|}{ CF } & \multicolumn{5}{|l|}{ Er } & & & \\
\hline & As & $\mathrm{Cd}$ & $\mathrm{Cr}$ & $\mathrm{Cu}$ & $\mathrm{Pb}$ & As & $\mathrm{Cd}$ & $\mathrm{Cr}$ & $\mathrm{Cu}$ & $\mathrm{Pb}$ & As & $\mathrm{Cd}$ & $\mathrm{Cr}$ & $\mathrm{Cu}$ & $\mathrm{Pb}$ & $\mathrm{DC}$ & PLI & PRI \\
\hline Mean & 4.28 & 1.48 & -0.9 & -3.3 & -1.6 & 29.5 & 4.6 & 0.8 & 0.2 & 0.5 & 295 & 139 & 1.6 & 0.8 & 2.6 & 35.6 & 1.52 & 438.5 \\
\hline Median & 4.30 & 1.34 & -0.9 & -3.0 & -1.8 & 29.6 & 3.8 & 0.8 & 0.2 & 0.4 & 296 & 114 & 1.6 & 0.9 & 2.2 & 34.8 & 1.40 & 406.6 \\
\hline SD & 0.21 & 0.58 & 0.4 & 0.6 & 0.5 & 4.3 & 3.0 & 0.2 & 0.1 & 0.2 & 43 & 89 & 0.4 & 0.3 & 0.9 & 6.6 & 0.33 & 118.8 \\
\hline Range & 0.64 & 2.17 & 1.2 & 1.7 & 1.4 & 13.1 & 10.5 & 0.7 & 0.2 & 0.6 & 131 & 315 & 1.4 & 0.9 & 2.8 & 24.0 & 1.15 & 447.7 \\
\hline Min & 3.97 & 1.00 & -1.5 & -4.2 & -2.1 & 23.5 & 3.0 & 0.5 & 0.1 & 0.3 & 235 & 90 & 1.1 & 0.4 & 1.7 & 28.0 & 1.25 & 330.1 \\
\hline Max & 4.61 & 3.17 & -0.3 & -2.5 & -0.7 & 36.6 & 13.5 & 1.2 & 0.3 & 0.9 & 366 & 405 & 2.5 & 1.3 & 4.5 & 52.0 & 2.40 & 777.8 \\
\hline$Q_{1}$ & 4.16 & 1.26 & -1.2 & -3.7 & -2.0 & 26.9 & 3.6 & 0.7 & 0.1 & 0.4 & 269 & 108 & 1.3 & 0.6 & 1.9 & 32.1 & 1.32 & 388.9 \\
\hline$Q_{3}$ & 4.38 & 1.41 & -0.7 & -2.9 & -1.3 & 31.2 & 4.0 & 0.9 & 0.2 & 0.6 & 312 & 120 & 1.8 & 1.0 & 3.0 & 36.5 & 1.60 & 428.4 \\
\hline
\end{tabular}

petrochemicals, wastewater irrigation, and atmospheric deposition (Khan et al. 2008; Zhang et al. 2010). Increasing levels of soil contamination with heavy metals may be transformed and transported to plant and from plants pass into animals and human (Atayese et al. 2010).

Arsenic is widely distributed in the environment. The studied soil samples contain a significant content of As ranging from 117.5 to $182.8 \mathrm{mg} / \mathrm{kg}$ with an average of $147.46 \mathrm{mg} / \mathrm{kg}$ (Table 3). This content is higher than the world soil As content (5 mg/kg, Kabata-Pendias and Mukherjee 2007).

Arsenic was known for its toxic effects on plants and animals. When plants were exposed to excess arsenic either in soil or in solution culture, they exhibited toxicity symptoms such as inhibition of seed germination, decrease in plant height, depress in tillering, reduction in root growth, decrease in shoot growth, lower fruit and grain yield, and sometimes leads to death (Marin et al. 1992; Carbonell-Barrachina et al. 1995; Kang et al. 1996; Abedin et al. 2002; Jahan et al. 2003; Rahman et al. 2004). Arsenic becomes part of the human solid food chain when products and fodder become contaminated. The most prominent chronic arsenic manifestations involve the skin, lungs, liver, and blood systems (Saha et al.

Table 5 Salinity ratings for soil based on electric conductivity

\begin{tabular}{|c|c|c|}
\hline Rating & $\mathrm{EC}(\mu \mathrm{S} / \mathrm{cm})$ & Effect on plants \\
\hline Non-saline & $0-2000$ & Salinity effects are mostly negligible \\
\hline Slightly saline & $2000-4000$ & $\begin{array}{l}\text { Yields of very sensitive crops } \\
\text { may be restricted }\end{array}$ \\
\hline Moderately saline & $4000-8000$ & Yields of many crops restricted \\
\hline Highly saline & $8000-16,000$ & $\begin{array}{l}\text { Only tolerant crops yield } \\
\text { satisfactory }\end{array}$ \\
\hline Extremely saline & $>16,000$ & $\begin{array}{l}\text { Only a few very salt-tolerant crops } \\
\text { yield satisfactory }\end{array}$ \\
\hline
\end{tabular}

1999). The significant difference between Q1 and Q3 (Fig. 5) suggests that its content is controlled by several intermixed processes, including the natural and anthropogenic, probably due to the special planting methods (Abdel-Hafiz 2017), because the sample with the high arsenic concentration was collected from an orchard farm. The application of pesticides and herbicides in orchard soils is intended to hinder insect pests and defoliation. This use increases the arsenic concentrations in the soil (De Gregori et al. 2003). Furthermore, As perhaps came from the rocks in the Eastern Desert during soil transportation and formation, where some serpentine rocks contain up to $75 \mathrm{mg} / \mathrm{kg}$ of As (Sadek et al. 2015).

The studied soil samples contain a significant content of Cadmium ranging from 1.5 to $6.75 \mathrm{mg} / \mathrm{kg}$ with an average of $2.31 \mathrm{mg} / \mathrm{kg}$ (Table 3). This content exceeds the average world soil $(0.5 \mathrm{mg} / \mathrm{kg}$, Kabata-Pendias and Mukherjee 2007). The close difference between Q1 and Q3 (Fig. 5) points to the uniform source and distribution of $\mathrm{Cd}$ in soil; this may be attributed to the application of P-fertilizers

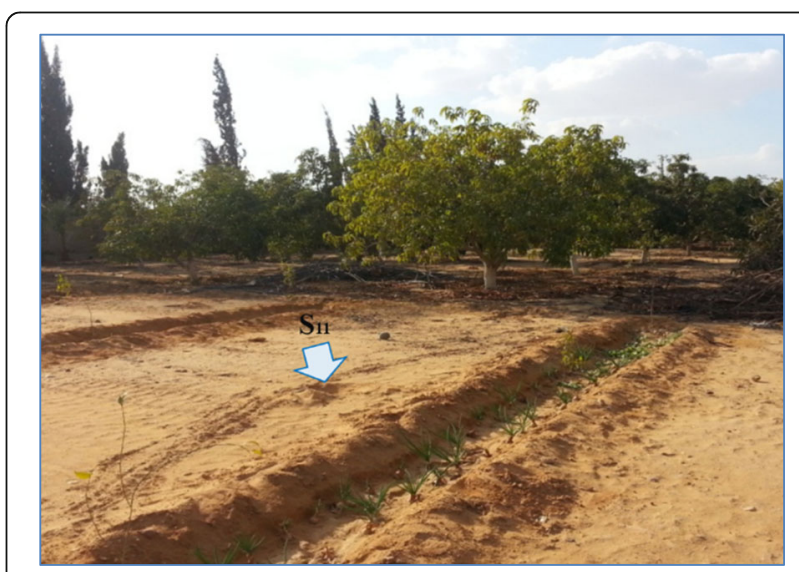

Fig. 3 Location of high salinity soil (S. No. 11) 


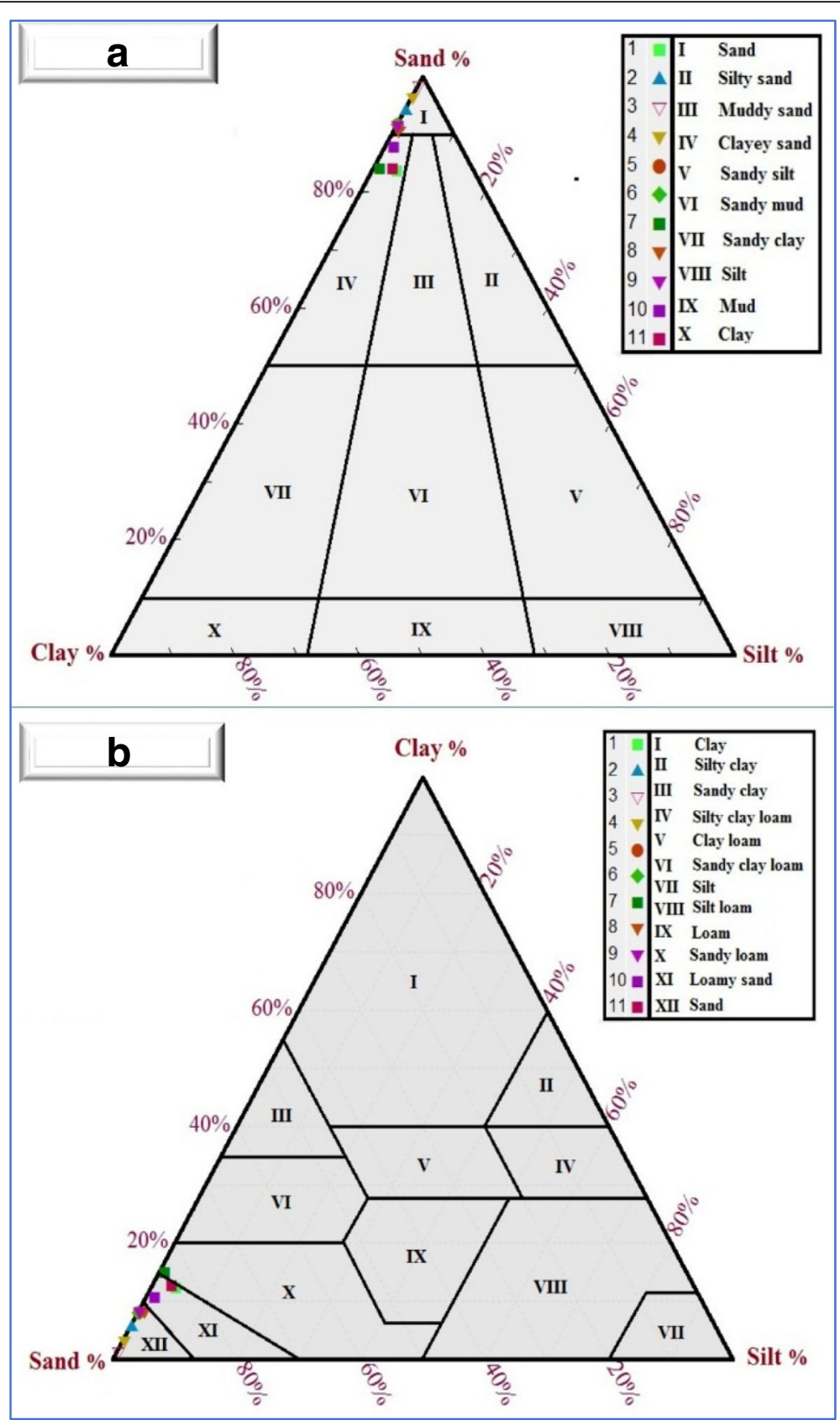

Fig. 4 Folk (a) and USDA (b) triangle diagrams of soil classification

which contains a considerable concentration of $\mathrm{Cd}$, about $12.45 \mathrm{mg} / \mathrm{kg}$ (Kabata-Pendias and Mukherjee 2007; Salman et al. 2016b). In addition, the adjacent ways may be contributed greatly to the pollution of soil with $\mathrm{Cd}$ (Elnazer et al. 2015).

Chromium is one of the known environmental toxic pollutants in the world. The measured $\mathrm{Cr}$ content in soil ranges from 29.05 to $67.25 \mathrm{mg} / \mathrm{kg}$ with an average value of $44.5 \mathrm{mg} / \mathrm{kg}$ (Table 3). Of all analyzed samples, $81.8 \%$ contain chromium level below the reported worldwide in surface soils of $54 \mathrm{mg} / \mathrm{kg}$ (Kabata-Pendias and Pendias 2001). The relatively close difference between Q1 and Q3 (Fig. 5) implies that the anthropogenic process is the main controlling factors in its distribution.

Copper is an essential micronutrient to nearly all higher plants and animals; in addition, it is an essential metal for crop plants. Total copper content in the examined soil ranges from 2 to $6.45 \mathrm{mg} / \mathrm{kg}$ with an 


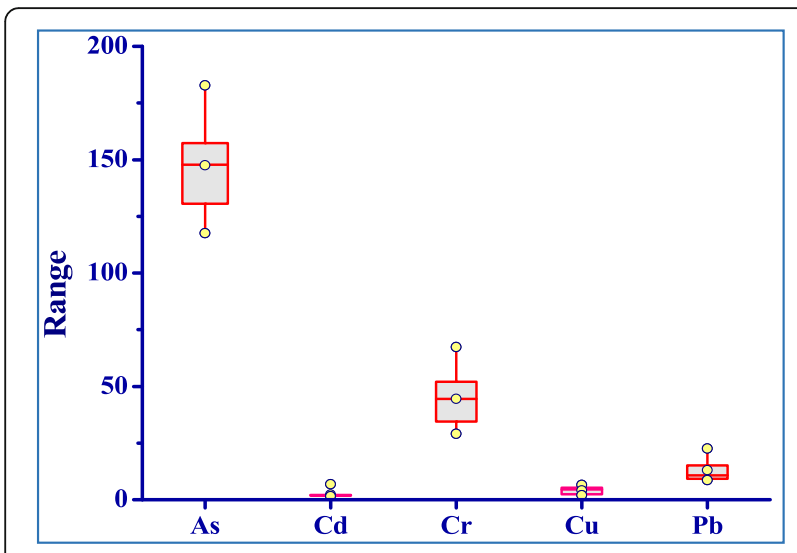

Fig. 5 Box-whisker graph showing soil heavy metals

average $4.1 \mathrm{mg} / \mathrm{kg}$. All the investigated samples recorded $\mathrm{Cu}$ values are below maximum allowable concentration of $25 \mathrm{mg} / \mathrm{kg}$ (Kabata-Pendias and Mukherjee 2007) (Table 3).

The measured lead content in soil ranges from 8.65 to $22.5 \mathrm{mg} / \mathrm{kg}$ with an average value of $13.01 \mathrm{mg} / \mathrm{kg}$. All the samples analyzed contain lead level lower than MAC.

The distribution patterns for heavy metals in the studied soil samples (for example Cd and As) show the highest concentration at the southeastern part (appears in sample 1) (Fig. 6) as a result of replacing the top $1.5 \mathrm{~m}$ of original soil in this location with other soil.

\section{Pollution risk assessment}

\section{Single pollution indices}

The calculated geoaccumulation index for the studied samples is illustrated in (Table 4 and Fig. 7a). The $I_{\text {geo }}$ of $\mathrm{Cr}, \mathrm{Cu}$, and $\mathrm{Pb}$ showed no pollution. While the majority of soil samples (nine samples) are moderately contaminated with $\mathrm{Cd}$. Moreover, the obtained $I_{\text {geo }}$ revealed that most of the samples (nine samples) considers heavily to extremely contaminated with As.

The calculated contamination factor (Table 4 and Fig. 7b) indicates that all the soil samples are highly polluted with As $(\mathrm{CF}>6)$. The $\mathrm{CF}$ of $\mathrm{Cd}$ showed considerable contamination in all samples except one sample considered high contamination. The $\mathrm{CF}$ of $\mathrm{Cu}$ and $\mathrm{Pb}$ in all samples showed low contaminated. Furthermore, the CF of Cr showed the majority of samples (eight samples) are low contamination, while it is moderately contaminated in three samples.

The calculated ecological risk (Table 4 and Fig. 7c) indicates that nearly all the soil samples have a high ecological risk with respect to As except samples (1 and 3) represented as very high ecological risk. In addition, the $\mathrm{Er}$ of $\mathrm{Cd}$ of indicates that nearly all samples are at considerable ecological risk except one sample has a very high ecological risk. Like $I_{\text {geo, the }}$ Er of $\mathrm{Cr}, \mathrm{Cu}$, and $\mathrm{Pb}$ indicates that the samples are at low ecological risk.

\section{Integrated pollution indices}

According to the DC values (Table 4 and Fig. 8), all samples are at high contamination degree. High values of $\mathrm{CF}$ for As and Cd reported from soil samples are the main reason for the wide band of high contamination category in the study area.

PLI is presented in (Table 4 and Fig. 8). The results of pollution load index were found to be high $(\mathrm{PLI}>1)$ in all the investigated samples. This indicates the high load of heavy metals in the studied soil samples. The PLI values for all samples are less than 1 indicating the role of external discrete sources, vehicle exhaust, and agricultural activities of soil pollution (Elnazer et al. 2015). These results indicate probable environmental pollution especially with hazards As and Cd.

PRI calculation results of samples (Table 4 and Fig. 8) showed considerable ecological risk except one sample no. (1) which showed very high ecological risk. The ecological risk comes mainly from soil pollution with As and $\mathrm{Cd}$. These two metals have the adverse impact on both the plants and human health and much attention must be paid to the study area quality.

\section{Conclusion}

As a result of this study, it was found that the studied soils are of alkaline nature, non-saline to slightly saline, and weakly calcareous soils. Regarding the textural characteristics, the Orabi soils are sand and clayey sand according to folk system, whereas based on the USDA system, it is sand, sandy loam, and loamy sand. Concentrations of arsenic and cadmium are above maximum allowable limits. While $\mathrm{Pb}, \mathrm{Cr}$, and $\mathrm{Cu}$ in more than $82 \%$ are below the upper critical limit. For single pollution indices, investigated soil samples were uncontaminated with $\mathrm{Cr}, \mathrm{Cu}$, and $\mathrm{Pb}$; moreover, considerably contaminated with $\mathrm{Cd}$ and highly contaminated with As. The calculated integrated pollution indices showed that investigated soil samples were varied from considerable contamination according to potential ecological risk index (PRI) values to high contaminated pattern according to pollution load index (PLI) and contamination degree (DC) results.

These results play an important role in order to determine soil quality and it can help the local authorities to take an action in term of remediation purposes. High values of $\mathrm{CF}$ for arsenic and cadmium reported from soil samples are mainly responsible for the wide band of high contamination category in the study area. Thus, increased contents of arsenic in agricultural soils have become a real problem. 


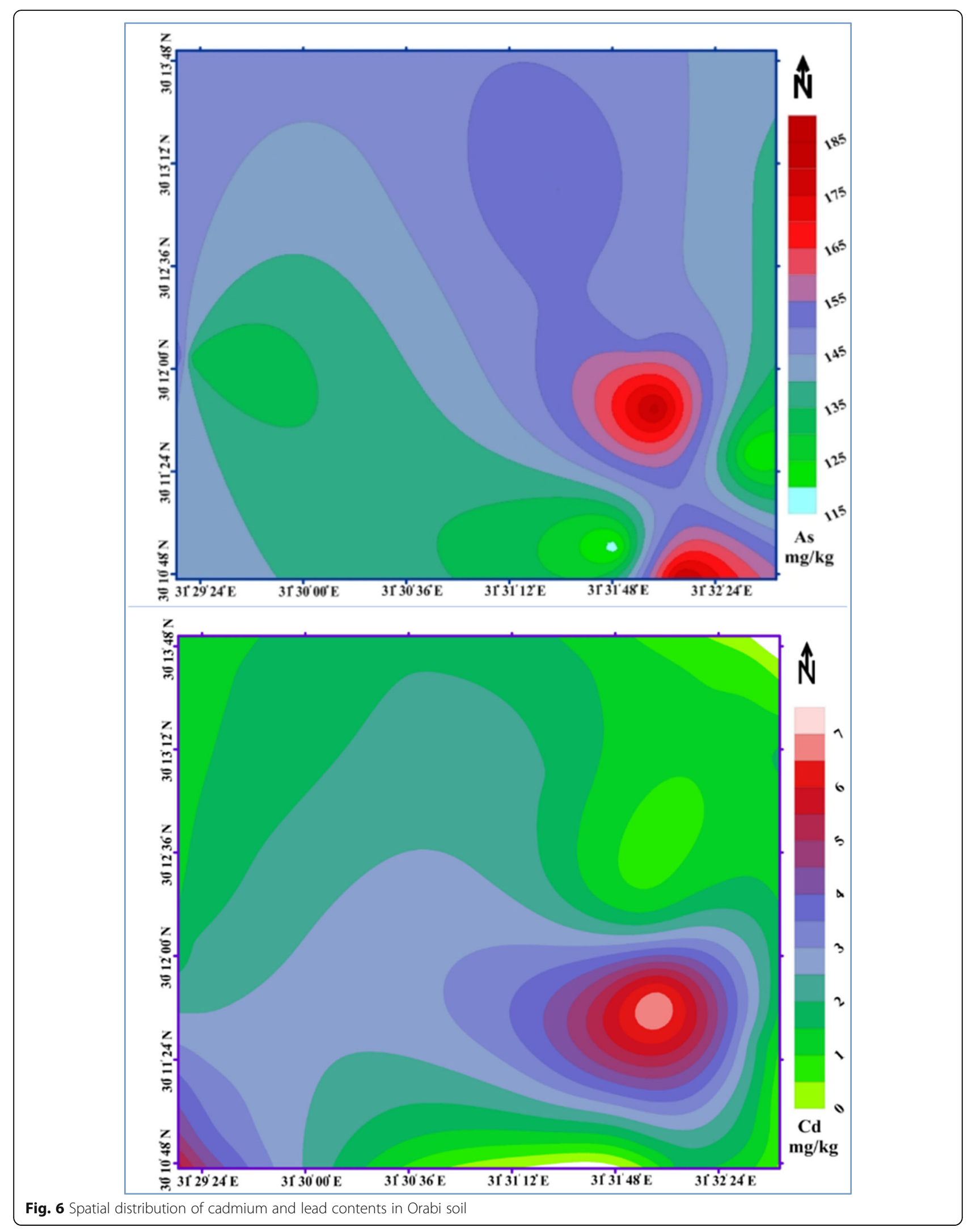




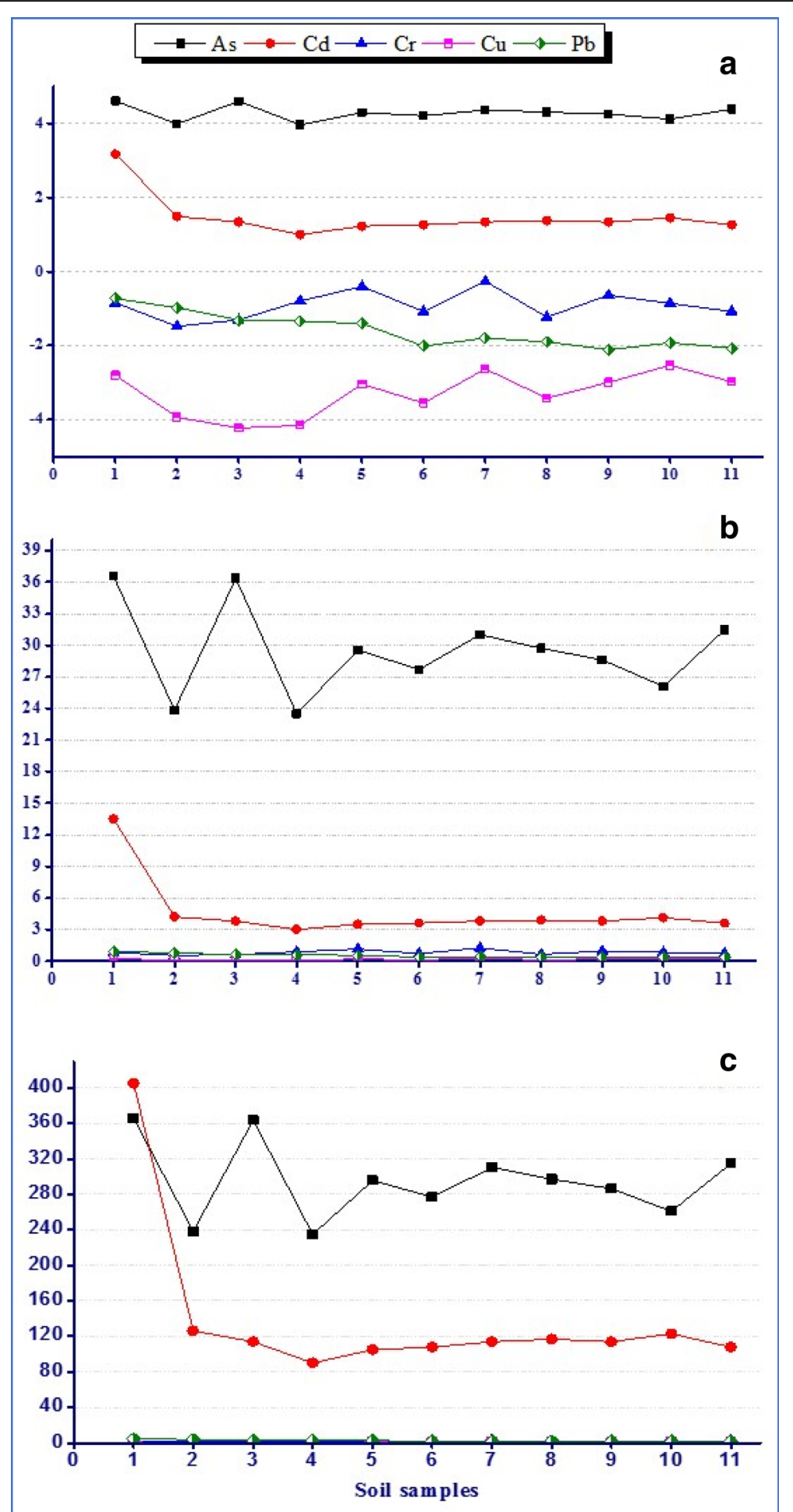

Fig. 7 Variation of $\mathrm{As}, \mathrm{Cd}, \mathrm{Cr}, \mathrm{Cu}$, and $\mathrm{Pb} \mathrm{I}_{\text {geo }}(\mathbf{a}), \mathrm{CF}(\mathbf{b})$, and $\mathrm{Er}(\mathbf{c})$ in Orabi farms 

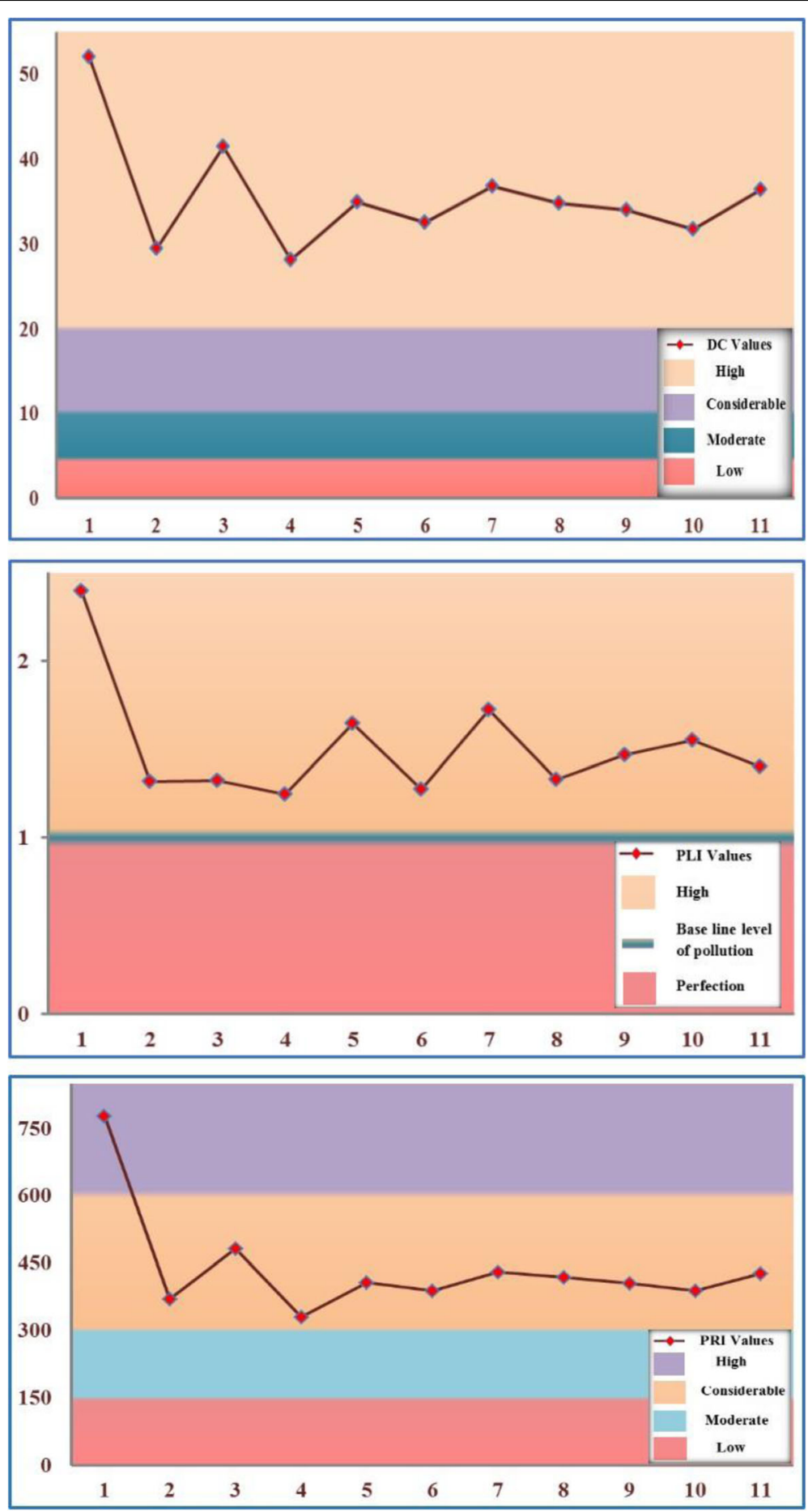

Fig. 8 DC, PLI, and PRI variations in Orabi farms 


\section{Acknowledgements}

The authors would like to thank the Geological Sciences Dept., National Research Centre, and geology Dept. Al-Azhar Univ. (Assiut Branch) for facilitating during this work.

\section{Funding}

Not applicable.

\section{Availability of data and materials \\ Not applicable.}

\section{Authors' contributions}

All authors contributed equally in all article steps. All authors read and approved the final manuscript.

\section{Authors' information}

Not applicable.

\section{Ethics approval and consent to participate} Accepted.

\section{Consent for publication}

Accepted.

\section{Competing interests}

The authors declare that they have no competing interests.

\section{Publisher's Note}

Springer Nature remains neutral with regard to jurisdictional claims in published maps and institutional affiliations.

\section{Author details}

'Geological Sciences Department, National Research Centre, Dokki, Giza, Egypt. ${ }^{2}$ Geology Department, Faculty of Science, Al-Azhar University, Assiut, Egypt.

\section{Received: 2 January 2019 Accepted: 5 March 2019}

Published online: 15 March 2019

\section{References}

Abdel-Hafiz MA (2017) Hydrochemical and environmental assessment of waterlogging and soil for different purposes at El Obour city, East Cairo, Egypt. MSc. Thesis, Geol dep., Fac Sci, Al-Azhar Univ, Assiut, vol 273. https:// doi.org/10.13140/RG.2.2.12793.67687

Abedin MJ, Cottep-Howells J, Meharg AA (2002) Arsenic uptake and accumulation in rice (Oryza sativa $\mathrm{L}$ ) irrigated with contaminated water. Plant Soil 240:311-319

Atayese MO, Eigbadon Al, Oluwa KA, Adesodun JK (2010) Heavy metal contamination of amaranthus grown along major highways in Lagos, Nigeria. African Crop Sci J 16(4):225-235

Bashour II, Sayegh AH (2007) Methods of analysis for soils of arid and semi-arid regions. FAO, Rome

Carbonell-Barrachina AA, Burlo-Carbonell F, Mataix Beneyto J (1995) Arsenic uptake, distribution and accumulation in tomato plants: effect of arsenic on plant growth and yield. J Plant Nutrition 18:1237-1250

Chon HT, Ahn JS, Jung MC (1997) Environmental contamination of toxic heavy metals in the vicinity of some Au-Ag mine in Korea. Proceedings of the fourth biennial SGA meeting Turku, Finland, pp 891-894

De Gregori I, Fuentes E, Rojas M, Pinochet H, Potin-Gautier M (2003) Monitoring of copper, arsenic and antimony levels in agricultural soils impacted and non-impacted by mining activities, from three regions in Chile. J Environ Monit 5:287-295

El-Bady MSM, Samy Y (2014) Geochemistry and heavy metals pollution of the bottom sediments at Bardawil lagoon, northern Sinai coast, Egypt. Egyptian 」 Geol 58:271-285

Elnazer AA, Salman SA, Seleem EM, Abu El Ella EM (2015) Assessment of some heavy metals pollution and bioavailability in roadside soil of AlexandriaMarsa Matruh highway, Egypt. Int J Ecol Article ID 689420. https://doi.org/10. 1155/2015/689420

Folk L (1974) Petrology of sedimentary rocks. Hemplill, Austin, Texas, p 182

Foth HD (1990) Fundamentals of soil science, 8th edn. Wiley, New York
Hafizur Rahman S, Khanam D, Mehedi Adyel T, Shahidul Islam M, Aminul Ahsan M, Akbor A (2012) Assessment of heavy metal contamination of agricultural soil around Dhaka export processing zone (DEPZ), Bangladesh: implication of seasonal variation and indices. Appl Sci 2:584-601. https://doi.org/10.3390/ app2030584

Hakanson L (1980) An ecological risk index for aquatic pollution control: a sedimentological approach. Water Res 14:975-1001

He Z, Li J, Zhang H, Ma M (2005) Different effects of calcium and lanthanum on the expression of phytochelatin synthase gene and cadmium absorption in Lactuca sativa. Plant Sci 168:309-318

Jahan I, Hoque S, Ullah SM, Kibria MG (2003) Effects of arsenic on some growth parameters of rice plant. Dhaka Univ. J Bio Sci 12:71-77

Kabata-Pendias A, Mukherjee AB (2007) Trace elements from soil to human. Springer Berlin Heidelberg, New York, p 550

Kabata-pendias A, Pendias H (2001) Trace elements in soils and plants, 3rd edn CRC press, Boca Raton, Florida, USA, p 403

Kang $\sqcup$, Li XD, Liu JH, Zhang XY (1996) The effect of arsenic on the growth of rice and residues in a loam paddy soil. J Jilin Agri Univ 18:58-61

Khan S, Cao C, Zheng YM, Huang A, Zhu YG (2008) Health risks of heavy metals contaminated soils and food crops irrigated with waste water in Beijing, China. Environ Poll 152:686-692

Manahan SE (1994) Environmental chemistry, 6th edn. Lewis Pub., CRC press, Florida, USA, p 811

Marin AR, Masscheleyn PH, Patrick WH (1992) The influence of chemical form and concentration of arsenic on rice growth and tissue arsenic concentration. Plant Soil 139:175-183

Muller G (1979) Schwermetalle in den sediments des Rheins-Veranderungen Seitte. Umschan 78:778-783

NSSCC (National Soil Survey Committee of Canada) (1965) Report on the sixth meeting. Held at Laval Univ, Quebec, P.Q, p 132

Proust D, Fontaine C, Dauger N (2013) Impacts of weathering and clay mineralogy on heavy metals sorption in sludge-amended soils. Catena 101 188-196

Qingjie G, Deng J, Xiang Y, Wang Q, Yang L (2008) Calculating pollution indices by heavy metals in ecological geochemistry assessment and a case study in parks of Beijing. J China Univ Geosci 19(3):230-241

Rahman MA, Rahman MM, Miah MAM, Khaled HM (2004) Influence of soil arsenic concentrations in rice (Oryza sativa L.). J. Sub-trop. Agric Res Dev 2:24-31

Richards LA (1954) Diagnosis and improvement of saline and alkali soils, US Dept Agri, Handb, vol 60. USDA, Washington, DC

RIGW (Research Institute for Ground Water) (1980) Groundwater studies for tenth of Ramadan city. Ministry of Irrigation, Cairo

Sadek MF, Ali-Bik MW, Hassan SM (2015) Late Neoproterozoic basement rocks of Kadabora-Suwayqat area, central Eastern Desert, Egypt: geochemical and remote sensing characterization. Arab J Geosci 8:10459-10479

Saha JC, Dikshit AK, Bandyopadhyay M, Saha KC (1999) A review of arsenic poisoning and its effects on human health. Environ Sci Techno 29(3):281-313

Salman SA, Elnazer AA, El Nazer HA (2016b) Integrated mass balance of some heavy metals fluxes in Yaakob village, South Sohag, Egypt. Int J Environ Sci Techno. https://doi.org/10.1007/s13762-016-1200-3

Salman SA, Zeid SA, Seleem EM, Abdel-Hafiz MA (2016a) Assessment of soil pollution with heavy metals in Orabi farms, El-Obour city, Egypt. In: The $54^{\text {th }}$ annual scientific meeting at the Egyptian mineral resources authority, GSE. https://doi.org/10.13140/RG.2.2.29570.89286

Singh A (2015) Land and water management planning for increasing farm income in irrigated dry areas. Land Use Policy 42:244-250

Soil Survey Staff (1993) Soil survey manual. UDSA Handb. No. 18. Government Printing Office, Washington, DC

Suresh KR, Nagesh MA (2015) Experimental studies on effect of water and soil quality on crop yield. Inter. Conf. On water Reso., coastal and ocean Eng. (ICWRCOE). Aquatic Procedia 4:1235-1242

Swapnil R, Chopra AK, Pathak C et al (2011) Comparative study of some physicochemical parameters of soil irrigated with sewage water and canal water of Dehradun city, India. Arch Appl Scie Res 3(2):318-325

Tam NFY, Wong YS (1998) Variations of soil nutrient and organic matter content in a subtropical mangrove ecosystem. Water Air Soil Poll 103(1-4):245-261

Tomilson DC, Wilson DJ, Harris CR, Jeffrey DW (1980) Problem in assessment of heavy metals in estuaries and the formation of pollution index. Helgolander Meeresuntersuchungen 33(1-4):566-575 doi.org/10.1007/BF02414780 
UNCCD (United Nations Convention to Combat Desertification). Egyptian National Action Program to Combat Desertification 2005. https://knowledge. unccd.int/sites/default/files/naps/egypt-eng2005.pdf

USDA (United States Department of Agriculture). Soil Survey Investigations. Soil Survey Laboratory Methods Manual, Washington, DC 1996; 3(42)

Walkley A (1947) A critical examination of a rapid method for determining organic carbon in soils. Effect of variations in digestion conditions and inorganic soil constituents. Soil Sci 63:251-263

Yonglong LU, Song S, Wang R, Zhaoyang LIU et al (2015) Impacts of soil and water pollution on food safety and health risks in China. Environ Int 77:5-15

Yuan C, Shi J, He B, Liu J, Liang L, Jiang G (2004) Speciation of heavy metals in marine sediments from the East China Sea by ICP-MS with sequential extraction. Environ Int 30:769-783

Zeid SAM, Seleem EM, Salman SA, Abdel-Hafiz MA (2018) Water quality index of shallow groundwater and assessment for different usages in El-Obour city, Egypt. J Mater Environ Sci 9(7):1957-1968

Zhang MK, Liu ZY, Wang H (2010) Use of single extraction methods to predict bioavailability of heavy metals in polluted soils to rice. Commu Soil Sci Plant Anal 41(7):820-831

Zhang YB, Deng AY, Zhuang TC (2003) Relation between soil salinity in intertidal zone and electric conductivity. Ecol Environ 12(2):164-165

\section{Submit your manuscript to a SpringerOpen ${ }^{\circ}$ journal and benefit from:}

- Convenient online submission

- Rigorous peer review

- Open access: articles freely available online

- High visibility within the field

- Retaining the copyright to your article

Submit your next manuscript at $\boldsymbol{\nabla}$ springeropen.com 